\title{
A Teoria Política Imperial
}

Ivo Coser

\section{Ivo Coser}

Professor associado no Departamento de Ciência Política da UFRJ.

Email: ivocoser@bol.com.br

ORCID: https://orcid.org/0000-0002-8010-1287

\section{Introdução}

O presente artigo busca analisar e sintetizar as ideias relacionadas aos principais temas institucionais durante o período imperial (1822-1889). Esse esforço pretende propor que este conjunto de ideias possa ser pensado como uma teoria política. Para tanto o artigo é organizado da seguinte maneira. Em primeiro lugar, apresenta a noção de teoria política no debate anglo-saxão a partir da chamada revolução behaviorista e a resposta proposta, principalmente, por Hannah Arendt e Isaiah Berlin. Neste tópico, propõe uma diferenciação entre a tarefa do historiador das ideias políticas e daqueles que se dedicam ao campo do pensamento social brasileiro. Sustentando uma especificidade contida no esforço da ciência política na análise das ideias. No terceiro item, apresento o que considero as interpretações clássicas sobre as ideias políticas brasileiras no período. Ao longo do artigo retomo esses autores, bem como aqueles que, mais recentemente, se debruçaram sobre o tema. No quarto item, analiso os temas que predominaram no debate político institucional:

Centralização/Federalismo, Poder Moderador e Representação Política. Conjugo a exposição destes com as interpretações sobre os mesmos. Desenvolvendo uma análise do seu conteúdo e, propondo um enfoque que justifique a ideia de uma teoria política imperial. Finalmente, na conclusão busco recuperar os aspectos discutidos sintetizando e fundamentando a ideia de uma teoria política imperial.

\section{A teoria política}

Observar a construção do campo de pesquisa Pensamento Político brasileiro pela Ciência Política conduz a um olhar retrospectivo que permite distingui-lo de outros esforços intelectuais. Tal construção não provém do objeto em si, mas do caminho acidental e dos materiais dispersos que o forjaram. Este percurso não Ihe confere um caráter menor quando comparado a outros campos do saber, pois todos possuem uma História particular feita destes acidentes. A construção do Pensamento Político brasileiro envolve um empreendimento intelectual distinto daquele levado a cabo pela História e pela Sociologia, as quais elaboram, respectivamente, uma História das Ideias Políticas no Brasil e um Pensamento Social brasileiro. 
O cientista político ao se debruçar sobre seu objeto deve ponderar três aspectos: (a) as questões que eram contemporâneas ao seu objeto; (b) a construções das famílias intelectuais e (c) as questões da sua contemporaneidade que o levam a esta pesquisa. Dessa forma, "iberismo", "americanismo", "liberais doutrinários", "autoritários instrumentais", "radicais de classe média" etc. estabeleceram chaves de leitura a partir das quais autores e argumentos foram analisados. Tal movimento esteve presente no próprio objeto, desta maneira Oliveira Vianna, Guerreiro Ramos estabeleceram, também, os antepassados da família a qual pertenciam e os seus adversários. A construção destas chaves leituras implica em apontar ideias que agrupem estes autores, em outras palavras, um conjunto de valores que formam um argumento, valores estes que ultrapassam um contexto histórico singular, reunindo, desta maneira, autores de épocas distintas. Ao mesmo tempo, o cientista político deve estar atento ao contexto histórico do seu objeto, as questões que os autores enfrentaram em sua época e o vocabulário político do período de maneira a capturar o sentido das ideias presentes no texto.

Neste sentido, diferentemente da História, o que move o pesquisador na Ciência Política é menos a reconstrução do contexto, e mais o diálogo estabelecido a partir das questões contemporâneas e o passado. Neste tipo de pesquisa a reconstrução dos valores que orientaram estas famílias implica, inevitavelmente, em ênfases que agrupam certos temas em detrimento de outros, tal movimento longe de se constituir numa traição para com seu objeto, ideia que poderia orientar uma pesquisa orientada pelo contextualismo histórico, representa antes o fato que lhe confere intensidade e relevância '. A construção do objeto "pensamento político brasileiro" na Ciência Política obriga ao pesquisador a um triplo movimento: (1) estabelecer as perguntas que a partir do presente considera relevante formular ao seu objeto; (2) reconstruir o contexto histórico e político do seu objeto e (3) debruçar-se sobre as interpretações existentes e as famílias intelectuais que foram construídas e que envolvem o seu objeto. Nenhum pesquisador debruça-se sobreo seu objeto limpo das interpretações anteriores; assumi-las é uma tarefa que contribui para o esclarecimento da sua relação com o objeto.

Por outro lado, a construção do campo Pensamento Político brasileiro desenvolveu ao longo do tempo uma atenção aos valores e a sua configuração num dado arranjo político. Tal aspecto o conduziu a uma reflexão distinta daquela presente no chamado Pensamento Social brasileiro. Esta articulação entre valores e arranjo político é decisiva para a pesquisa do cientista político. Na análise do cientista político seu objeto de pesquisa apresentou, em vários casos, reflexões sobre a formação social e histórica do Brasil. Desta maneira, o par conceitual civilização/sertão presente no pensamento político imperial ganha maior complexidade ao longo dos anos 1920 a 1940, principalmente a partir das análises de Oliveira Vianna, Nestor Duarte e Victor Nunes Leal. Entretanto, esta análise mais complexa da formação social brasileira não conduz aos mesmos valores políticos e ao mesmo desenho institucional. Conforme pretendo apontar mais adiante, o diagnóstico sobre a formação social brasileira foi compartilhado nos seus traços fundamentais por diversas famílias intelectuais, mas foi pensado a partir de valores políticos distintos os quais conduziram à desenhos institucionais radicalmente diferentes. $O$ desenho institucional não é uma forma ornamental, a partir dele, em certos contextos, tornam-se explícitos valores que estão presentes em outras esferas da sociedade. 
Uma abordagem que pode contribuir para o estudo do pensamento político brasileiro seria aquela que desloca a atenção do autor, como o senhor do texto, e a desloca para os conceitos mobilizados por este e pelos seus contemporâneos. A partir do conflito em torno dos conceitos podemos recortar os conflitos relevantes que perpassaram aquele contexto, gerando uma análise que ultrapassa o estudo monográfico sobre um único autor e seu estilo de argumentação.

Um ponto de contato pouco explorado nas análises sobre o pensamento político brasileiro tem sido a possibilidade de analisa-lo como uma reflexão de teoria política. Vários pontos podem ser úteis nesta aproximação. Em primeiro lugar, o pensamento político brasileiro esteve sempre marcado por uma perspectiva comparada, ou seja, uma atenção à construção das instituições em países modernos e aqueles com formação semelhante a do Brasil. Esta reflexão conduziu, em vários momentos, a uma discussão acerca da natureza da política. A análise comparada foi o caminho a partir do qual foram apresentados juízos sobre a natureza da política. Instituições políticas foram pensadas tanto em relação a sua aplicabilidade ao contexto nacional quanto em relação a sua aos valores que elas acarretavam. De forma mais clara, a transposição das instituições nunca esteve dissociada de uma reflexão sobre a natureza da política e dos seus valores. Em segundo lugar, este diálogo com a Teoria Política, permite reconsiderar um aspecto distintivo na análise da maneira pela qual o campo de pesquisa Pensamento Político brasileiro foi construído dentro da Ciência Política brasileira: a inexistência de um debate acerca do caráter científico dos argumentos produzidos no pensamento político brasileiro - aspecto ao qual voltaremos mais adiante.

A Teoria Política apesar de partir da Filosofia Política apresenta um conjunto de preocupações distintas, possui um modo autônomo de pesquisa, nem filosófico nem movido por uma pretensão de ser uma ciência. Os problemas da teoria política não dizem respeito apenas ao bom ou mau funcionamento dos mecanismos institucionais, mas são problemas políticos, porque dizem respeito à relação entre estes e os valores que os orientam (BERLIN, 1998; WOLIN, 1969). Em segundo lugar, a Teoria Política está voltada para uma compreensão da maneira pela qual estes valores ganham forma no mundo, em outras palavras, a Teoria Política realiza uma reflexão acerca do fazer, preocupação que constitui a sua razão de ser como um campo específico na Ciência Política (SARTORI, 1981). Este esforço de observar e compreender os valores que orientaram o fazer não implica em uma negação do carácter científico das correntes políticas, não existe um Pensamento Político brasileiro pré-científico e um póscientífico. Os valores que orientaram a construção dos argumentos são parte integrante do seu alcance teórico. A Teoria Política empreende um esforço em assumir os valores políticos que orientam a reflexão como parte do conhecimento, o mundo da doxa jamais pode ser superado por um método científico do estudo da Política. 0 mundo da política se revela de formas diferentes para os autores em razão do local que eles escolhem para falar (ARENDT, 2005).

Tomar a Teoria Política como um esforço que assume o mundo da doxa como parte integrante do conhecimento implica em recusar a ideia de que um contexto político prévio aos esforços intelectuais. O contexto se revela de maneira distinta para os atores em razão do local que cada ator estabeleceu para si. Em outras palavras, o contexto é construído a partir dos diversos valores que os atores adotam. Neste sentido, o contexto é retirado do próprio texto. Tal suposição toma o texto como um 
espaço no qual transitam diversos conceitos, sem que o autor seja o sujeito absoluto destes. Deslocar o olhar do texto permite que o pesquisador possa mobilizar diversas fontes que não apenas o próprio texto escrito. Neste sentido, quando mobilizamos a ideia de argumento estamos pensando num todo que envolve tanto as ideias de um autor específico, quanto outros materiais de autorias diversas como discursos, panfletos ou artigos de jornais, mas que reúnem valores comuns.

\section{As interpretações sobre as ideias políticas no período Imperial}

As reflexões políticas produzidas durante o período Imperial projetaram sua sombra sobre os períodos subsequentes, seja pelo reconhecimento explícito da influência ou pela presença de temas que recorrentemente retornaram ao debate, dentre os quais podemos assinalar: Centralização/Federalismo, Poder Moderador, República/Monarquia, Representação Proporcional/Distrital e Ditadura.

Ao longo de todo debate político imperial, e, também durante a República, foi usual o uso da referência à cópia, a importação de ideias sem atenção para com a formação histórica social brasileira. Entretanto, a chave de leitura que interpreta as ideias política imperiais como cópia, recebeu um tratamento mais complexo posteriormente a partir dos trabalhos de Raymundo Faoro e Roberto Schwarz.

O trabalho de Schwarz se afigura como um ponto de partida importante porque permite abordar dois tópicos: a) o papel das ideias liberais e b) a exclusão social das classes subalternas. Em primeiro lugar, Schwarcz recusa tomar as ideias liberais como algo descartável, estas eram mesmo "indescartáveis" (SCHWARCZ, 2000). Na Europa, o Liberalismo foi pensado num contexto da passagem do trabalho feudal para 0 trabalho assalariado, enquanto no Brasil o trabalho escravo e a grande propriedade e sua ação simplificadora sobre a estrutura social desempenhavam um papel decisivo, ocorrendo uma inadequação entre o seu conteúdo e o meio. Esta inadequação decorre do movimento que oculta a segregação dos pobres. É o silêncio sobre esta segregação que limita o alcance das ideias produzidas no Brasil. Seguindo a lógica do autor, é típico que várias correntes liberais deplorem a escravidão, mas temam pelos seus efeitos da sua abolição, fato que leva a uma auto contenção que limita o seu alcance. A relação entre o moderno e o atraso permanece inconclusa, pois o atraso termina sub-repticiamente, como uma realidade mais profunda e mais forte, moldando a 0 alcance destas ideias.

A incapacidade das ideias liberais em operar uma ruptura com a ordem colonial foi, também, um aspecto importante no argumento de Raymundo Faoro sobre o Pensamento Político brasileiro. $\mathrm{O}$ autor ao se perguntar se existe um pensamento político brasileiro aponta a continuidade, na ex-colônia portuguesa na América, da revolução irrealizada. O patrimonialismo como um fenômeno de Estado teria bloqueado a emergência das ideias liberais. As quais, no seu contexto original, operaram uma revolução política, representando a vitória da sociedade civil contra o absolutismo. Com a emergência do contratualismo, os problemas da política passaram a ser pensados a partir do indivíduo e seus direitos, os quais eram fixados em direção contrária a ordem estamental. No Brasil, estas ideias circulam e configuram a identidade política dos atores, mas sua incorporação ao Estado traz a marca da cooptação, ao invés da representação dos interesses. O Estado brasileiro disporia de uma autonomia em relação à sociedade civil, abafando o mundo dos interesses 
privados e inibindo a livre iniciativa. Suas instituições políticas teriam a marca das concepções organicistas conduzindo à afirmação da racionalidade burocrática e do Direito Administrativo em detrimento da ordem racional legal e do Direito Civil. A ruptura que importa, para o argumento de Faoro, é, principalmente, com o Estado patrimonial. Saquaremas e liberais moderados estão vinculados por uma lógica de ferro: organizar o poder e limpá-lo das impurezas despóticas e do arbítrio, mas sem tornar o poder proveniente do povo. As ideias liberais hegemônicas não afirmaram os direitos do cidadão, mas foram, antes uma técnica de organização do Estado (FAORO, $1994: 82$ ).

As ideias liberais e seu papel no pensamento político brasileiro e na construção das instituições políticas foi, também um aspecto abordado por Richard Morse (1998). A linha interpretativa deste autor foi depois aprofundada por vários autores, mas, principalmente por Werneck Vianna e Maria Alice Rezende de Carvalho. A tese de Morse nos interessa menos pela sua aplicação ortodoxa, e, mais pelas releituras que propiciou. Caso seguíssemos a linha interpretativa formulada por Morse teríamos que considerar que as ideias liberais foram apenas o verniz que adornou móveis de madeira mais antiga e persistente, quais sejam, o Tomismo e suas derivações. Entretanto, não é este o caminho nos interessa. A releitura do trabalho de Morse apresentou duas grandes correntes no pensamento político brasileiro: americanismo e iberismo. $\mathrm{O}$ argumento americanista sustentava a precedência do interesse individual como o motor do desenvolvimento econômico e político, enquanto que no iberismo predominavam os temas associados à Nação entendida como uma comunidade (BARBOSA FILHO, 2000; WERNECK VIANNA \& CARVALHO, 2000).

\section{Os temas do Império: Justiça, centralismo-federalismo, representação, Poder Moderador}

O processo de independência coloca em primeiro plano a internalização do processo decisório. Nesse processo, as elites políticas são retiradas do seu isolamento colonial e obrigadas a elaborar instituições políticas capazes de sustentar um Estado nacional que abarca regiões diversas entre si, e, entendidas já na época, como não dispondo de vínculos sociais e econômicos entre si. Esse processo forçou as elites rurais elaborar instituições segundo padrões cosmopolitas, longe do tradicionalismo vinculado à dominação patrimonial (FERNANDES, 1975).

A pergunta que condensa os diversos tópicos do debate político imperial naquele momento pode ser resumida da seguinte maneira: como unir regiões que não possuem vínculos sólidos entre si, como construir instituições que formem um todo organizado, quando não há uma nação, mas arquipélagos isolados? Nesta pergunta estavam presentes duas dimensões que nunca foram separadas no pensamento político imperial em suas diversas vertentes políticas: como tornar as instituições eficientes e, ao mesmo tempo, representativas.

Quando é aberto o debate sobre a maneira pela qual os poderes estariam distribuídos na sociedade brasileira dois modelos disputam as opiniões: o modelo unitário e o modelo confederativo, também chamado de federativo. $\mathrm{O}$ argumento confederativo/federativo postulava que o centro da vida política estava nas províncias, com a Independência os laços entre estas e o poder central estariam desfeitos, sendo necessário que fosse formulado um novo pacto que deveria reconhecer esta 
autonomia. Neste modelo, não desaparece o poder central, mas ele é antes um poder coordenador entre unidades que dispõem de autonomia. Esta ideia central implicava em reformular todas as instituições políticas que estavam sendo delineadas pela corrente unitária: o Poder Moderador, o Conselho de Estado e o Senado vitalício. Bem como em adotar um controle da justiça no mínimo compartilhado com as províncias. Neste primeiro momento os termos Confederação e Federalismo eram usados indistintamente, com o predomínio do conteúdo do primeiro ii. Uma das principais vozes desta corrente foi Frei Caneca (cf. FREI CANECA, 2001). As referências escassas à República estavam sempre associadas ao tema da confederação/federação, sendo esta forma de governo vista como a mais adequada à descentralização. Entretanto, os exemplos das ex-colônias espanholas e de São Domingos tinham um peso considerável em refrear a propaganda republicana. Era disseminado o receio que a república conduzisse à fragmentação, a uma guerra civil e a revoltas escravas (LEITE, 2000).

O argumento unitário apontava para a necessidade da unidade e da concentração de poderes no poder central em detrimento da autonomia provincial. Ao longo da conjuntura política à este modelo foram associados diversos valores, sem que haja uma contradição entre estes. Num primeiro momento, grosso modo, durante o primeiro reinado, a centralização é associada a existência de um poder que congregue as diversas províncias, evitando o caminho das ex-colônias espanholas. A reação conservadora, iniciada a partir do final da década de 30, mantém este discurso, mas coloca em movimento outras ideias que serão fundamentais para o argumento centralizador. O poder central necessitaria de funcionários que estivessem submetidos ao seu controle, estes funcionários deveriam, se possível, possuir um treinamento específico. Os funcionários deveriam circular pelo país de maneira que não estabelecessem vínculos com a localidade. As normas que regeriam estes funcionários seriam as normas escritas vinculadas pelo poder central, sem que o funcionário se guiasse por normas locais, fruto de relações pessoais iii.

O argumento federalista operava com valores distintos. A legislação descentralizadora teve dois momentos que se refletiram em ênfases e valores distintos. O primeiro momento foi marcado pela elaboração de leis que colocavam importantes funções no nível municipal. Nesta esfera seriam eleitos ou escolhidos para as funções do judiciário os cidadãos da localidade, sem necessariamente disporem de uma formação para o seu exercício, o que era requisitado era o reconhecimento dos cidadãos. Neste sentido, a ideia de federalismo passava a estar associada à imagem de que o poder público seria disseminado pela sociedade, ficando mais próximo aos cidadãos. A esfera mais próxima aos cidadãos era a municipal.

O argumento federalista reconhecia que os cidadãos brasileiros não possuíam uma prática que os tivesse educado para esta legislação. O país teve uma formação histórica diversa daquela dos Estados Unidos, o argumento federalista não desconhece a base social brasileira. Não eram movidos por um liberalismo utópico ou doutrinário que obtusamente buscavam ofuscados pelo exemplo estadunidense. A legislação colonial teria mantido os cidadãos distantes do envolvimento nos assuntos públicos. Esta ideia implicava em considerar que a participação política num sistema representativa somente poderia ser internalizada através de uma educação prática, ao invés de aguardar a difusão material da civilização pelo país, quando então, os cidadãos poderiam participar da política no seu nível mais próximo, o município. 0 argumento dos liberais exaltados mobilizava para a construção do Estado-nação os 
interesses imediatos do cidadão sem recorrer a virtudes estranhas a estes, não permeava o tema da grandeza territorial como um móvel para a ação o cidadão, mas apenas seus interesses imediatos na segurança da sua propriedade que mediados pelos instrumentos participativos conduziria a montagem da máquina pública.

Entretanto, este primeiro movimento logo será revisto, quando as atribuições postas no município passarão a serem controladas pela assembleia provincial. Conjuntamente a este deslocamento ocorrerá uma importante reformulação do conceito de federalismo. A experiência estadunidense e sua reformulação da definição de federalismo será percebida no debate brasileiro, os elementos políticos de uma confederação serão amputados em favor de um arranjo federativo, no qual os estados serão partes não soberanas submetidas à União. Esta compreensão terá consequências chaves no debate brasileiro. Em primeiro lugar, federação não implica em separação, o poder central pode dispor de poderes efetivos. Em segundo lugar, a província dispõe de assuntos que devem ser regidos segundo seus interesses. Em terceiro lugar, o pacto federativo deve ser montado de maneira a que as províncias tenham liberdade para buscar seus interesses. Cada província buscando seus interesses termina por contribuir para o bem público, sendo inclusive, saudável certa rivalidade entre as províncias (COSER, 2008b). Esta redefinição apresenta outra modificação decisiva, o arranjo federativo será pensado não mais a partir da participação do cidadão ao nível municipal, mas a partir da província, e, principalmente, da assembleia provincial (BASTOS, 1937).A experiência regencial revelou a inaplicabilidade da descentralização a partir do município com apoio nos interesses do cidadão. O ponto focal passa a ser a assembleia provincial, a qual é eleita não a partir de distritos, modelo que levaria a eleição dos potentados locais, mas através de votação em toda a província, fato que reforça o poder dos chefes políticos nacionais. Cada assembleia provincial deveria dispor de autonomia para adequar as leis nacionais referentes à justiça de acordo com seus interesses. Não era possível, como escreveu Tavares Bastos, que as mesmas leis regessem o Mato Grosso e São Paulo. O federalismo era um meio que deveria permitir que não apenas os interesses provinciais moldassem a política nacional, mas que também os interesses particulares encontrassem espaço, afastando o imperativo do interesse nacional como um laço que deveria reconfigurar os interesses particulares.

As décadas de 1850 e 1860 assistem à emergência de valores novos ao argumento centralizador: as liberdades civis e o direito administrativo. Os direitos civis teriam precedência sobre os direitos políticos, tratava-se de assegurar o exercício destes, para tanto a principal ameaça ao seu exercício provinha do poder privado, mais especificamente dos potentados rurais e seus dependentes. Nesta lógica armar o poder central de instrumentos era a maneira de assegurar os direitos civis, invertendo um ponto clássico do liberalismo anglo-saxão para o qual um poder central forte seria uma ameaça às liberdades civis. Esta visão é apresentada em linhas gerais pelo Visconde de Uruguai, e será depois, retomada por Oliveira Vianna (CARVALHO, 1999; SOUZA, 1997; OLIVEIRA VIANNA, 1987). O segundo aspecto será a associação entre centralização e direito administrativo. Com o direito administrativo o argumento centralizador recebe a ideia de que o poder central expressaria o interesse geral, o cidadão seria movido por interesses particulares, os quais são reconhecidos como legítimos. Entretanto, esses interesses somente recebem seu sentido último quando são redefinidos a partir da lógica do interesse nacional, conforme estabelecido pelo poder central. Esta ideia foi fortemente influenciada pelo liberalismo francês, em particular dos doutrinários franceses. Tal perspectiva reconhece as províncias como 
possuidoras de assuntos que lhe são próprios e que devem ser decididos segundo os interesses específicos, bem como os interesses dos cidadãos, mas as obriga a considera-los em termos de interesses gerais.

O alcance destas alterações no argumento saquarema pode ser menor caso consideremos algumas análises. O espaço para a autonomia provincial e municipal é bastante reduzido, pois estas são entendidas como correias de transmissão dos valores e políticas presentes no poder central, bloqueando, desta maneira, a emergência dos interesses provinciais. Ao mesmo tempo, a interferência do poder central nos conflitos políticos na província e no município a partir de sua burocracia em nome da pacificação oculta os interesses concretos do grupo situado no poder central (FERREIRA, 1999). Esta interferência do poder central nos conflitos armados entre os grandes proprietários pode ser entendida não como um choque, mas como uma ação da coroa com o objetivo de ordenar e civilizar os interesses da grande propriedade (MATTOS, 1994).

Nas diversas correntes do pensamento político imperial, liberais exaltados, liberais moderados e saquaremas, emerge o conflito com as ações da grande propriedade rural quando esta busca frear as ações da justiça com base em motivos retirados do patrimonialismo tradicional vigente na sociedade. No ataque à estas concepções como escreveu Florestan Fernandes: "O liberalismo não aparece no cenário nacional como conexão da preservação do passado." É do conjunto das ideias liberais, lidas a partir de considerações acerca da especificidade da situação nacional, que estes grupos irão retirar seus argumentos para o ataque. Esse conjunto de ideias liberais apresenta três faces. Por um lado, ele aponta para o futuro para o qual a nação deve se orientar (RAMOS, 1966), por outro qualifica os cidadãos capazes de participar e exclui outros e, silencia sobre a reforma da grande propriedade. Os efeitos negativos da grande propriedade e da escravidão sobre o sistema político são apontados em diversos momentos do pensamento político imperial (CARVALHO, 1988). Uma corrente aponta para a funcionalidade da escravidão no sistema econômico mundial, o seu desaparecimento ocorreria na medida em que esta deixasse de atender a certas funções do mercado. Uma segunda corrente sustenta a necessidade do fim da escravidão com base nos prejuízos que esta causava para a formação da nação (ANDRADA E SILVA, 1988; NABUCO, 2000). A escravidão era, apesar da sua funcionalidade interna, menos produtiva que o trabalho livre, sua existência criava uma imagem negativa para o trabalho, impedia a formação de uma sociedade homogênea socialmente e conduzia grande parte dos cidadãos que não se enquadrava nos dois polos para o serviço público, em resumo, a escravidão bloqueava a formação de uma nação moderna.

Como operar as mudanças que conduziriam a nação a uma sociedade liberal moderna? Saquaremas, liberais moderados e liberais exaltados concebem o liberalismo como um destino que guia as ações no presente, mas que somente será realizado plenamente no futuro (FERNANDES, 1970). A política e a ação do Estado não são mobilizadas como meios para a mudança econômica, o lento expandir da civilização conduziria inteligentemente as transformações de uma sociedade patrimonial para uma sociedade liberal moderna, sem que a unidade nacional se rompesse, fato que traria resultados negativos para toda a sociedade (WERNECK VIANNA, 1997).

Esta noção do ritmo do tempo social não é rompida sequer quando os liberais moderados atacam os três pilares do argumento saquarema: a centralização, o Poder 
Moderador e o modelo de representação política. Quando Tavares Bastos aponta que o fato que distorce e impede a representação da sociedade brasileira no Estado vem a ser a intervenção do governo (BASTOS, 1975) está presente nesta ideia quatro pontos centrais. Tornar o Estado representativo da sociedade retirando a intervenção do governo implica em descentralizar, dar livre vazão aos interesses particulares, afastar a intervenção do Poder Moderador e reformar a representação.

O debate político acerca do papel do Poder Moderador apresentou duas posições (TORRES, 1964): uma sustentava que a despeito da adoção da forma monárquica, o imperador não possuía nenhum poder acima da representação nacional presente na assembleia geral, como consequência ele não deveria possuir nenhum poder, sendo sua função a de simbolizar a unidade nacional. A segunda corrente sustentava dois aspectos. Primeiro que a atuação decisiva do monarca no processo de independência havia estabelecido um fato: a existência de um centro dotado de poderes. Tal fato havia sido reconhecido pela sociedade brasileiro desde o momento em que demandou a sua presença, enfrentando as cortes portuguesas. Em segundo lugar, que este centro dotado de poderes era necessário como o poder que controlasse os eventuais choques no parlamento e as forças centrífugas existentes na sociedade. Ocorre que dentro desta atribuição de freio era posto também, e este era o pomo maior da discórdia, a tarefa de chefiar o executivo. Ao longo do primeiro reinado, os grupos liberais exaltados ou moderados enfrentaram um monarca que lhes negava 0 direito de contestar suas políticas. A sua abdicação e o período regencial afastou 0 tema do poder moderador do centro do debate. Entretanto, o debate retornou em parte com novos acentos ao final da década de 1850 (BUENO, 2002; SOUZA, 1978; SOUZA, 1997; VASCONCELOS, 2002).

Os liberais moderados sustentavam que ao monarca cabia a tarefa de simbolizar a unidade nacional, o rei reina, mas não governa. De maneira a acomodar o papel do monarca previsto na constituição os liberais moderados distinguiam entre ação e deliberação. O monarca participava da deliberação, mas não da ação. A coroa pode legalmente exercer a mais extensa e decisiva influência, pois lhe cabe velar pelo bem geral da nação, mas a ação pertence exclusivamente aos responsáveis da ação, quais sejam, os ministros (VASCONCELOS, 2002). O que implicava em conferir autonomia aos ministros e torna-los responsáveis somente perante o presidente do conselho de ministros e, consequentemente, ao legislativo. Neste argumento, o valor do legislativo como reunião das opiniões políticas da sociedade desempenha um papel relevante, o legislativo deve ser um canal no qual se expressam as opiniões, mas também deve participar do governo. Em outras palavras, o ato de representar não está dissociado de governar. A vontade política da nação está presente não apenas em uma figura que expressa o interesse nacional numa única voz, mas num órgão do qual emergem diversas vozes, concorrentes entre si, cada qual expressando uma visão do que seja o interesse nacional. A crítica ao exercício do Poder Moderador pode ser sintetizada a partir de um trecho de um discurso de Nabuco de Araújo largamente, difundida a partir do livro do seu filho. Segundo este, não existiria representatividade nos ministérios porque estes são organizados segundo a vontade do Poder Moderador. Ao desfazer os ministérios segundo sua vontade, refaz também a câmara. Isto somado ao seu poder em escolher o senado em lista tríplice, torna o sistema representativo no país uma farsa (NABUCO, 1997; NOGUEIRA, 2010). Este diagnóstico deu vazão a duas vertentes de análise: a primeira de que o Poder Moderador agia sem limites, sendo um instrumento político proveniente do absolutismo ao antigo regime; a segunda, em 
grande parte construída por Oliveira Vianna, que o Monarca agindo acima dos partidos, das eleições e do parlamento realizava uma política fundada nos interesses nacionais, e que o sistema liberal representativo era tão somente uma via para a expressão de interesses particulares. Uma análise mais consistente do seu funcionamento e, que ajuda a compreender os valores de cada argumento, revela outra realidade política (CARVALHO, 1988). Em primeiro lugar, 11 das 17 legislaturas foram dissolvidas, das quais 10 foram feitas após consulta ao Conselho de Estado, em apenas três casos o Imperador contrariou o voto do Conselho. Em todos os outros casos havia conflito entre o ministério e a câmara ou o senado. Estes conflitos eram decorrentes do fato de que os partidos não possuíam a solidez, além do que eram frequentes as dissidências decorrentes de caráter provincial e ideológica. Em segundo lugar, a queda de um ministério implicava, geralmente, na convocação de novas eleições, fato que abria a possibilidade de uma rotatividade no poder.

É importante abrirmos a duas máximas para dispor de uma análise mais complexa dos argumentos envolvidos. A ideia dos liberais moderados era deslocar o centro do poder para a câmara, a qual caberia formar o governo. Os chefes políticos nacionais de cada partido desempenhariam um papel importante na formação dos ministérios. Com o afastamento do papel ativo do Poder Moderador, os ministros passariam a responder apenas ao Presidente do Conselho e ao legislativo. Diminuiria o centro de poder que os saquaremas valorizavam, um centro que deveria ser estável e imune ao máximo às oscilações do parlamento. $O$ argumento saquarema defende um centro de poder que disponha de áreas de atuação autônomas. A introdução do direito administrativo francês, operada pelos saquaremas, buscava legalizar uma destas áreas.

$\mathrm{O}$ ataque ao Poder Moderador realizado pelos liberais moderados vai pari passu a defesa de uma maior representatividade das eleições (LYNCH, 2014). O tema da maneira pela qual a sociedade seria representada no parlamento foi um dos focos de maior debate político ao longo de todo o Império (PINTO, 1983; CARVALHO, 1988; KINZO; 1980; SOUZA, 1978). Fato que denota a centralidade do tema da construção da representação em moldes liberais.

A relação entre o parlamento, o locus da representação, o executivo e o Poder Moderador está longe de ser uma relação de submissão absoluta do primeiro para com o executivo, e, consequentemente, para com o Imperador. As pesquisas mais recentes abandonaram alguns dos pressupostos clássicos e encararam a tarefa de abrir os debates e analisar o regimento do parlamento de maneira a descortinar o seu funcionamento. Tal tarefa Ihes permitiu delinear claramente que o parlamento dispunha de mecanismos, e, de usá-los concretamente, para refrear o executivo e de indicar alternativas às políticas propostas por aquele (DOLHNIKOFF, GREGORIO, FRANCISLEIDE, SAEZ E SALES, 2011). Esta perspectiva oferece um substrato fundamental para repensar a reflexão sobre representação no período imperial. Esta está longe de ser um enunciado de teorias exógenas ao "país real". A discussão sobre a representação está ancorada existência de um parlamento como ator do sistema político, ao mesmo tempo que indicava como a representação deveria ser construída. As duas dimensões nunca estiveram separadas na teoria política imperial.

O tema da representação esteve sempre associado a dois valores: a) como representar uma nação que não dispunha de uma opinião pública e b) como evitar as câmaras unânimes, em outras palavras, como assegurar a representação das minorias. Este segundo tópico revela a presença de um valor chave no pensamento político 
imperial, a ideia de que na sociedade existem diversas correntes políticas, e, que tal fato não poderia ser sufocado em nome de um interesse nacional uniforme, este quando emerge é o resultado, antes de um debate político, do que de um ato de força. $\mathrm{O}$ embate que cedo ocorreu entre as elites políticas nativas e um Imperador, que se apresentava como o portador e formulador do interesse da nação, revelou aos grupos nativos a importância do reconhecimento das divisões políticas existentes na sociedade. Que o parlamento estivesse dividido em partes, correntes de opinião e que estas ganhassem voz no parlamento não era um problema, ao contrário o problema era como fazê-las serem representadas (VASCONCELOS, 1999; COSER, 2014).

A visão de um país profundamente marcado pelo par conceitual civilização/sertão nos permite interpretar as semelhanças e diferenças entre saquaremas e liberais moderados. Ambos compartilhavam da ideia de que o Brasil era um país marcado por pequenos e reduzidos espaços de civilização e vastas áreas nas quais predominavam os valores do sertão. Os valores predominantes no sertão marcavam a todos os grupos sociais indistintamente, do grande proprietário rural até os seus dependentes. Neste sentido, representar implicava em depurar certos valores presentes na sociedade. A representação para seguir o modelo liberal que orientava liberais e saquaremas tinha que operar de tal maneira que os valores predominantes neste espaço social fossem contidos no âmbito do poder central ou no âmbito da assembleia provincial.

Um dos termos que marca este debate está no receio de que as celebridades de aldeia predominassem no parlamento nacional. Tal receio ganhou forma na lei dos círculos (1855), a qual buscou atingir três pontos: a) diminuir a influência do governo através da inelegibilidade de funcionários públicos nos locais onde exercessem seus cargos; b) por o representante em contato com os eleitores locais e, consequentemente $c$ ) dar voz às maiorias locais evitando que estas fossem sufocadas pelas elites políticas nacionais. A lei vigorou, com alterações, entre 1857 e $1875^{\mathrm{iv}}$, e representou uma mudança no perfil do parlamento: houve uma queda no número dos funcionários públicos e o começo do aumento dos profissionais liberais (CARVALHO, 1988). O argumento que atacava este modelo se concentrava em dois valores: a) os deputados, e senadores eleitos devem sair dos mais capazes, daqueles capazes de expressar os interesses nacionais, os quais não estão dados na sociedade, mas são antes a descortinados e construídos no parlamento pela ação dos representantes e b) as lutas políticas nas localidades, também denominadas como partes do sertão, são marcadas pelo facciocismo e pelo uso violência, os conflitos desencadeado nas das instituições nacionais são de outra natureza, são de princípios e não podem ser contaminadas por este padrão.

A crítica mais consistente e singular contra o voto distrital foi desenvolvida por José de Alencar. O sistema proporcional assegura dois aspectos chaves: a) que todas as correntes de opinião significativas estejam presentes e b) o representante não esteja preso aos interesses de uma localidade, mas a interesses mais gerais. Quanto maior for o círculo eleitoral maior a gama de interesses representados, a representação se nacionaliza, e ganha em qualidade (ALENCAR, 1991: 59). Em contrapartida, ocorre uma menor dependência para com os interesses locais. O representante não é o porta voz dos representados, a ele cabe a tarefa de construir os interesses nacionais, ele é um órgão da razão (ALENCAR, 1991:46). Em que pese esta autonomia do representante, o processo eleitoral é fundamental. Segundo Alencar, o cidadão não 
pode permanecer afastado do debate político, quando a representação espelha os interesses nacionais o cidadão é educado pela participação, em outras palavras, o processo eleitoral efetua uma educação cívica, que não ocorreria caso ele fosse apartado (ALENCAR, 1991:86). Alencar retoma um valor chave dos liberais exaltados do começo do século XIX, num país sem educação cívica, sem o habito da participação nos assuntos públicos, somente o envolvimento prático nestes pode criar cidadãos plenos. Quando observamos o debate político nacional esta mistura entre a defesa da nacionalização do debate político e a defesa da participação é um dos elementos que conferem singularidade a Alencar.

Ao mesmo tempo, a reflexão de Alencar foi retomada como singular não apenas em relação ao debate político nacional, mas quando comparada aos seus contemporâneos, principalmente Stuart Mill e Tocqueville. A sua singularidade reside na sua maior densidade democrática, ele efetua uma combinação entre representação democrática e representação proporcional. A democracia não é apenas a vontade da maioria, mas é também a representação proporcional das diversas correntes políticas, quanto mais proporcional a representação mais democrática; a participação deve pertencer a todos aqueles que contribuírem para a riqueza da nação sem distinção de renda; o governo democrático é o governo do todo, e deve evitar tanto a tiranida da maioria como o veto das minorias, o mandato é tanto mais democrático quanto menor for a sua duração (SANTOS, 1999). Tal originalidade não cancela o seu pertencimento ao debate político imperial, mas permite liga-lo a outras vertentes da teoria política.

A crítica saquarema à lei dos círculos nos permite interpretar os valores fundamentais do seu argumento acerca da representação. A primeira baliza deste consiste na ideia de quanto maior o distrito eleitoral maior a possibilidade de que 0 representante represente interesses mais amplos do que aqueles presentes na localidade. O representante deixa de ser diretamente dependente dos potentados locais, pois deve sua eleição à sua penetração em vários pontos da província, esta entrada era devida aos grandes chefes políticos nacionais os quais desempenhavam um papel-chave. Esta autonomia do representante permite que ele exerça uma depuração dos interesses imediatos dos seus eleitores. Este papel ativo do representante jamais implicou que o argumento saquarema pretendesse cancelar os mecanismos políticos que produziam a representação e os partidos, sem estes o Brasil cairia no caudilhismo hispano-americano.

O argumento liberal moderado passa a defender a eleição direta e a representação como uma expressão dos interesses locais e provinciais. O pensamento liberal moderado defendia a eleição direta na medida em que a nova lei eleitoral havia elevado os pré-requisitos para o voto reduzindo o corpo eleitoral. 0 argumento liberal moderado pode agora defender que os interesses imediatos do povo sejam expressos diretamente sem a mediação do representante pois, pressupõe que tenha ocorrido uma depuração no corpo eleitoral. O qual estava contaminado pelas classes mais rudes da população (BASTOS, 1975:143). A assembleia nacional, a reunião dos diversos interesses situados na província, será com a neutralização do poder moderador, o centro do poder político. A depuração do eleitorado encontrará respaldo numa análise da formação histórica e social do Brasil tecida desde a independência. A sociedade brasileira entendida a partir de uma dicotomia civilização/sertão era compartilhada por saquaremas e liberais moderados. O cidadão situado nos vastos sertões era, como escreveu Tavares Bastos, o produto de falta de estrada e de escolaridade vivendo na 
dependência dos ricos (BASTOS, 1975: 143). Tal julgamento era compartilhado pelos saquaremas, essa sociologia avant la lettre irrigava uma análise sobre os vícios dos eleitores os quais somente poderiam ser corrigidos pelo lento espraiar da civilização. Está presente nesta visão, uma análise social que não acredita nos efeitos do exercício político, proporcionado das instituições liberais a partir da expansão dos direitos políticos, sobre os cidadãos do vasto sertão.

Quando foi proposta a redução do corpo eleitoral, ambos os segmentos já haviam construído uma visão que legitimava seu afastamento. Solitariamente Joaquim Nabuco apontou que este ato era contrário ao pensamento liberal, o qual seguia em direção contrária, qual seja, no sentido da expansão dos direitos políticos (NABUCO, 1950). O projetar na monarquia um ator capaz de realizar reformas sociais, a abolição da escravidão e uma política de terras que democratizasse o seu acesso foi o projeto de André Rebouças. O qual como Nabuco pensou que a monarquia após ter realizado a obra da unidade nacional deveria adotar um projeto social, o qual complementaria a sua obra (CARVALHO, 1988) `.

Esta visão de reforma social esteve ausente do argumento republicano vencedor. $O$ argumento republicano é influenciado pelos valores da dissidência liberal dos anos 1870 e pelo positivismo. O republicanismo não é apenas uma continuidade, mas também apresenta elementos novos o que lhe confere uma radicalidade para com a herança imperial (ALONSO, 2002; FERNANDES, 2008). Alberto Sales foi um dos principais expoentes do Republicanismo Federal de São Paulo. Partindo da ideia do interesse individual como a mola da sociedade, tema já enfatizado por Tavares Bastos, sustentava que a sociedade era eminentemente competitiva, mas tal fato não deveria ser visto como negativo, pois esta era a mola do progresso (SALES, 1882). Ao Estado caberia proteger a liberdade de iniciativa e os direitos civis e políticos. Para que esta proteção fosse eficaz, o poder do Estado deveria ser limitado, dividido e delegado à nação. As liberdades formalmente reconhecidas na constituição estavam, de fato, bloqueadas pela centralização monárquica. Caberia à República incluir a nação no sistema político. A república é apresentada como o corolário lógico destes pressupostos, pois seria a forma de governo que repelindo toda espécie de poder irresponsável e hereditário, coloca a vontade nacional acima de tudo; não reconhece outra soberania que não seja a da nação (ASSIS BRASIL, 1888:40). Além da república e entranhada à esta forma estava o federalismo, afastada qualquer possibilidade de que através deste modelo houvesse um movimento separatista, esta organização emergia como sendo a mais propícia para que as unidades da união buscassem a realização dos seus interesses. A centralização imperial era um obstáculo para as províncias, em particular São Paulo, dessem vazão as iniciativas individuais (SALES, 1983). A América hispânica exemplo sempre evocado pelos saquaremas como ameaça do que poderia ocorrer com o Brasil caso adotasse o federalismo e a república, agora era mobilizada como um exemplo positivo. A Argentina era citada como um país que progredia mais rapidamente que o Brasil. No argumento republicano tratava-se de acelerar o tempo histórico, não se podia mais confiar no lento espraiar da civilização regulado pelas instituições monárquicas, era preciso romper com passado para o país progredir. 


\section{Conclusão}

$\mathrm{O}$ argumento de Schwarz reconhece a funcionalidade das ideias liberais, em nenhum momento ele nega este papel. O que ocorre é que a sua falsidade decorre da exclusão ao que estão submetidos os pobres. Se o argumento de Schwarz tem o mérito de apontar para esta exclusão, ele perde de vista um elemento fundamental. A chave de entrada para analisar pensamento político imperial consiste em perceber a tensão que é produzida entre as ideias movidas por valores liberais e o contexto nacional. Existe no pensamento político imperial uma tensão para com o contexto que perpassa todas as correntes políticas. Todos trazem no seu argumento um esforço em adequar ideias ao contexto e, ao mesmo tempo, em modernizar a sociedade marcada pelas relações patrimoniais e escravistas. Como bem observou Florestan Fernandes, no período pós independência a centralização era um instrumento a partir do qual o Estado era mantido distante do localismo predatório das elites locais. Preservar o Estado significava preservar as instituições políticas liberais das pressões do mandonismo local. Tal movimento ao mesmo tempo limitava a representação fidedigna desta sociedade. As ideias liberais nos seus diversos matizes, liberais moderados, exaltados ou conservadores- eram dotadas de uma carga de tensão para com o meio social marcado pelo mandonismo. Em todas estas correntes esteve presente a ideia de que a superação deste meio social adverso seria um trabalho lento, no qual as ideias modernas iriam lentamente educando a sociedade. É esta tensão que confere inteligibilidade ao objeto.

A chave de leitura proposta por Faoro destaca a limpeza efetuada nos elementos absolutistas provenientes do mundo lusitano, mas revela também a incapacidade de absorver a nação no seu elemento popular. Faoro aponta, como também o faz Ricúpero, a influência decisiva do liberalismo doutrinário francês. O qual se afasta tanto do jacobinismo como do antigo regime (FAORO, 1975: 346; Ricupero, 2004 :45-81). Em ambos esta recepção é lida apenas como depuração do elemento popular. Ambos perdem de vista o papel fundamental que direitos civis e os interesses individuais desempenharam no argumento saquarema. Este argumento não os nega, mas estes somente ganham sua plenitude quando são conduzidos a funcionar segundo a lógica da nação. Uma lógica que não está presente na dinâmica dos interesses particulares, mas que requer uma visão do todo, da nação. Sua análise foi precisa ao identificar os valores dos liberais exaltados e moderados, mas, quando se deteve no argumento saquarema perdeu de vista a inserção deste grupo no campo de um liberalismo distinto daquele marcado pelo mundo anglo saxão, sua lógica provinha de uma recepção do liberalismo doutrinário francês lido a partir do contexto nacional (ROSANVALLON, 1985).

A chave de leitura oferecida por Morse, do americanismo e do iberismo, é extremamente rica desde que pensemos que ela pode ser aplicada sem que recuemos no impacto das ideias liberais sobre o pensamento político brasileiro. $\mathrm{O}$ argumento saquarema e luzia é inteligível desde que compreendamos que se trata de um caminho distinto das ideias liberais anglo-saxãs, que a filiação política do liberalismo saquarema pertence ao liberalismo francês.

Quando o trecho do discurso de Nabuco de Araújo sobre o poder moderador é aprofundado podemos perceber uma realidade mais complexa. O poder moderador não funciona desligado de outras instituições, operando na maior parte das vezes como um freio entre os grupos. Afastando a ideia de que o poder moderador 
funcionasse sem peias podemos refletir também sobre o tema da representação. Qualquer sistema representativo pretende por em relevo certos aspectos em detrimentos de outros, sistemas eleitorais não são meios neutros. A discussão sobre representação no Império pretendeu depurar os elementos mais vivos do patrimonialismo presentes na sociedade. Conjuntamente a esta depuração, foi pensada a extensão dos direitos políticos aos homens pobre livres, sua presença foi um elemento estranho nesta discussão. Quando a reforma eleitoral os retirou poucas foram as vozes a seu favor.

Perante a pergunta existe uma teoria política brasileira? é possível elaborar uma resposta. Em primeiro lugar, é necessário estabelecer que por teoria política entendemos uma reflexão que recolhe opiniões sobre o fazer política. $O$ entendimento do mundo social se relaciona diretamente com os valores que são projetados sobre as instituições que regulam o poder. Não há uma separação entre a compreensão do mundo social e as instituições, nem tampouco uma divisão em como elas funcionam e como devem funcionar. A teoria política abarca tanto o estudo dos valores presentes nas instituições quanto a maneira pela qual elas operam. Sem que estas duas dimensões estejam apartadas. Essa teoria é original? Considero que a recepção das ideias liberais foi feita tendo em vista as condições sociais e históricas presentes na sociedade brasileira. Nesse esforço, os valores liberais foram fundamentais para projetar sua ruptura com o passado colonial. Nesse sentido, ela representa um esforço em produzir um campo de ideias distinto daquele presente na reflexão seja de matriz anglo-saxã ou francesa.

O presente artigo colocou em destaque o papel das ideias liberais tendo em vista esta perspectiva. As diversas correntes políticas manusearam as ideias liberais europeias nos seus matizes específicos, mais democráticos, menos democráticos, liberais moderados, de maneira crítica. Depurando e adaptando em função do seu entendimento do par conceitual civilização/sertão e dos valores escolhidos. No final da década de 20 e começo de trinta, os liberais exaltados reconhecem a adversidade do meio social, mas consideram que a prática repetida e a força dos interesses seriam capazes de educar os cidadãos. Numa lógica semelhante, Nabuco defendeu a expansão dos direitos políticos. Existem valores que perpassam o contexto histórico específico e imprimem sua marca nos autores. O pensamento saquerema enfatizou 0 papel da centralização, do poder moderador e representação política depurada do vasto sertão sem separar tais instituições dos valores e das instituições liberais. Sua matriz foi antes o liberalismo doutrinário francês do que a forma anglo-saxã. Não sem razão, um dos seus projetos institucionais foi a adaptação do direito administrativo. Com sua noção de que os indivíduos possuem direitos, independentemente da sua situação social, e que os interesses destes são a mola do progresso social. Entretanto, para o exercício do poder político, estes interesses particulares devem ser inoculados com valores que não se encontram presentes na sua manifestação natural. Tal injeção provém dos interesses públicos lidos e aplicados pela elite política. Ocorre que tal operação nunca é pensada separada das instituições liberais e do seu funcionamento. A ideia de um poder autoritário por cima da sociedade dispensando as eleições, os partidos e o parlamento seria, para os saquaremas, a capitulação para com o sertão e o abandono do alentado projeto de modernização da sociedade.

No vasto contingente de ideias gestadas no Império, as teorias tomam como ponto de partida a incorporação de ideias liberais em um contexto distinto daquele no 
qual elas foram gestadas. É fundamental estabelecer que não há uma teoria liberal original, no próprio seu leito de nascimento é ela, também um amálgama de experiências e valores que permitem recepções distintas.

Em todas as matrizes políticas imperais há utopia e realismo, expostos de maneira explícita. Há valores postulados e observação empírica sobre o funcionamento das instituições. Compara-se o funcionamento das instituições europeias e estadunidenses com o caso brasileiro. Conjuntamente a este balanço entre utopia e realismo, a teoria política imperial conjuga a construção de instituições representativas em moldes liberais. A representação política foi sempre pensada em função da ideia de que a construção da vontade política não poderia ser apartada dos valores referentes à competição, disputa e confronto entre opiniões. O governo deveria ser o resultado do embate entre grupos que dentro de limites estabelecidos lutam pelo voto e implementam uma dada política. O interesse nacional é uma casa na qual cabem várias opiniões distintas, uma casa que não é harmônica, mas conflituosa. Todas correntes postulam o interesse nacional, mas reconhecem que este não nasce fora do sistema liberal, como um ato de um ator externo. Tal ideia foi combinada com a visão de que a representação liberal era uma tradução e uma depuração do país real. O país real era uma base heterogênea, marcada por regiões civilizadas e vastos sertões, o qual não podia ser ocultado nem traduzido plenamente, mas antes era a tarefa das elites controlar os sertões. Com vistas a construir este sistema liberal. Este esforço em conjugar utopia e realismo com a construção de uma representação em bases liberais consiste na melhor contribuição da teoria política imperial ao debate brasileiro.

(Recebido para publicação em setembro de 2020)

(Reapresentado em setembro de 2020)

(Aprovado para publicação em outubro de 2020)

\section{Cite este artigo}

COSER, Ivo, 2019. A Teoria Política Imperial. Revista Estudos Políticos: a publicação semestral do Laboratório de Estudos Hum(e)anos (UFF). Rio de Janeiro, Vol.11 | N.1, pp. 41-62, outubro de 2020.

\section{Notas}

1. O contextualismo histórico refere-se a corrente teórico que confere ênfase a reconstrução do contexto histórico a partir de uma pesquisa que envolve diversas fontes, documentos, panfletos, discursos, livros etc. os quais permitiriam identificar as intenções do autor e precisar o conteúdo dos termos utilizados. Tomamos como um exemplo desta abordagem, Pocock, 1989. 
2. Esse uso indistinto entre os termos era comum na época, como indica Tocqueville (Democracia na América, p.123).

3. Para uma análise detalhada do debate em torno dos diversos cargos, cf. Coser (2008a).

4. Em 1860 a lei foi alterada para permitir a eleição de três deputados ao invés de um (PORTO, 1989).

5. A expressão política deste projeto está parcialmente contida no último ministério monárquico, cujo projeto do Visconde de Ouro Preto previa alargar o eleitorado e estimular a difusão do ensino primário.

\section{Referências bibliográficas}

ALENCAR, José de. O sistema representativo. In SANTOS, W.G. (org.) Dois escritos democráticos, Rio de Janeiro, Ed. UFRJ. (1ed. 1868), 1991, p 1-184.

ALONSO, Angela, 2002, Ideias em Movimento: a geração 1870 na crise do Brasil-Império. São Paulo, Ed. Paz e Terra.

ANDRADA E SILVA, José Bonifácio de. Representação à Assembleia Geral Constituinte e Legislativa do Império do Brasil sobre a escravatura. (1823), 1988 In Projetos para o Brasil (org.) Miriam Dolhnikoff. São Paulo: Companhia das Letras, p.45-86.

ARENDT, Hannah. Sócrates. In Jerome Kohn. A promessa da política. São Paulo, Ed. Difel, 2009: 4584.

ASSIS BRASIL, Joaquim Francisco, A República Federal. In A democracia representativa na República (antologia) Brasília, Ed Senado Federal. 1983 (1ed. 1881):23-87.

BARBOSA FILHO, Rubem. Tradição e Artifício. Belo Horizonte: Ed. UFMG; Rio de Janeiro:IUPERJ, 2000.

BASTOS, Aureliano Candido Tavares. A Província. 1937(1ª ed. 1870), 2 ed., São Paulo: Ed. Nacional.

BASTOS, Aureliano Tavares, Reforma Eleitoral e Parlamentar da Constituição da Magistratura. In Os males do presente e as esperanças do futuro., São Paulo: Ed. Nacional, 1975 . (1.ed. 1873), 1976: 135177. 
BERLIN, Isaiah,. Ainda existe a teoria política? In: HARDY, Henry \& HAUSHEER, R. (orgs.). Estudos sobre a humanidade. São Paulo: Companhia das Letras. 2002 : 99-130.

BOTELHO, André. Sequências de uma sociologia Brasileira. In Dados, Vol. 50, N. 1. Rio de Janeiro, 2007: 49-82.

BRANDÃO, Gildo Marçal, Linhagens do Pensamento Político brasileiro. São Paulo, Aderaldo \& Rothschild editores, 2007.

BUENO, José Antônio Pimenta. Direito Público Brasileiro e Análise da Constituição do Império. In José Antônio Pimenta Bueno. Org. introd. Eduardo Kugelmas, São Paulo, ed. 34, (1ª ed. 1857) 2002.

CARVALHO, José Murilo de Federalismo e Centralização no Império brasileiro: História e argumento. In Pontos e Bordados: escritos de História e Política. Belo Horizonte, Editora UFMG. 1999: 155-189.

CARVALHO, José Murilo de, Escravidão e Razão Nacional. In Pontos e Bordados: escritos de História e Política. Belo Horizonte, Editora UFMG. 1999:35-81

CARVALHO, José Murilo de. A utopia de Oliveira Vianna. In Pontos e Bordados. Belo Horizonte, Ed. UFMG, 1999:202-233.

CARVALHO, José Murilo de. A Construção da Ordem. Brasília: Ed. UnB, 1980.

CARVALHO, José Murilo de. Teatro de Sombras. São Paulo: Ed. Vértice, 1988.

CARVALHO, José Murilo de. Mandonismo, coronelismo, clientelismo: uma discussão conceitual. In Pontos e Bordados. In Pontos e Bordados. Belo Horizonte, Ed. UFMG, 1999: 130-155.

CARVALHO, Maria Alice Rezende de. O quinto século: André Rebouças e a construção do Brasil. Rio de Janeiro: Revan: IUPERJ-UCAN, 1988.

COSER Ivo e HOLLANDA, Cristina Buarque de. Liberais e autoritários orgânicos: a questão da representação política nas obras de José de Alencar, Assis Brasil, Gilberto Amado, Alberto Torres e Oliveira Vianna. In Dados vol.59, no.3, : 903-946, 2016. 
COSER, Ivo, O conceito de Federalismo e a Ideia de Interesse no Brasil do Século XIX. In Dados, Rio de Janeiro, volume 51, n.4, : 941-981, 2008.

COSER, Ivo Visconde do Uruguai: Centralização e Federalismo no Brasil (1823-1866). Belo Horizonte, Editora UFMG, 2008.

COSER, Ivo, O conceito de partido no debate político brasileiro (1820-1920) In Ler História, 67, Lisboa, Portugal : 107-129, 2014.

DOLHNIKOFF, M., GREOGORIO, Vitor, MAIA, Francisleide, SALLES, Pedro Paulo. Representação política no Império, Crítica à ideia do falseamento institucional. In LAVALLE, Adrian G. (Org.). El horizonte de la política no Brasil. Brasil y la agenda contemporânea de investigación em el debate internacional. Cidade do México,: CIESAS, 2011: 125166.

FAORO, Raymundo. Existe um pensamento político brasileiro? São Paulo, Ed. Ática, 1994.

FAORO, Raymundo. Os Donos do Poder. Volumes 1 e 2. Porto Alegre, Ed. Globo, 1984.

FERNANDES, Florestan, Questões preliminares de Importância Interpretativa. In A Revolução Burguesa no Brasil: ensaio de interpretação sociológica. Rio de Janeiro, Zahar : 15-30, 1975.

FERNANDES, Florestan, Ciência e sociedade na evolução social do Brasil. In A sociologia no Brasil: contribuição para o estudo e desenvolvimento de sua formação e desenvolvimento. Rio de Janeiro, Vozes, 1976 (1ed. 1956): 25-49.

FERREIRA, Gabriela Nunes. Centralização e descentralização no Império. $O$ debate entre Tavares Bastos e o Visconde do Uruguai. São Paulo, Editora 34, 1999.

FRANCO, Maria Sylvia de Carvalho. Homens Pobres Livres na ordem escravocrata. $4^{a}$ edição. São Paulo. UNESP, 1997.

FREI CANECA, Joaquim do Amor Divino, Organização e introdução de Evaldo Cabral de Melo. São Paulo, Ed. 34, 2001

GUERREIRO RAMOS, Alberto. O formalismo, no Brasil, como estratégia para mudança social. In Administração e Estratégia do Desenvolvimento, Rio de Janeiro, Fundação Getúlio Vargas:331-422, 1966. 
KINZO, Maria Dalva Gil Representação política e Sistema Eleitoral no Brasil. São Paulo, Edições Símbolo.

LEAL, Victor Nunes Coronelismo, enxada e voto. São Paulo, Alfa-Omega, 1982

LEITE, Renato Lopes. Republicanos e Libertários: pensadores radicais no Rio de Janeiro (1822). Rio de Janeiro, Ed. Civilização Brasileira, 2000.

LYNCH, Christian Edward Cyrill, Por que Pensamento e não Teoria ? In Dados, Vol. 56, n 4, Rio de Janeiro :.727-767 : 2013

LYNCH, Christian Edward Cyrill. Da monarquia à oligarquia: História institucional e pensamento político brasileiro. São Paulo, Alameda, 2014.

MATTOS, IImar Rohloff. O Tempo de Saquarema: a formação do Estado Imperial. Rio de Janeiro, Ed. Acess, 3a edição, 1994.

MORSE, Richard. O Espelho de Próspero. São Paulo: Companhia das Letras, 1988.

NABUCO, Joaquim. O Abolicionismo. Rio de Janeiro, Nova Fronteira, (1883), 2000.

NABUCO, Joaquim, Um estadista do Império. Rio de Janeiro, Topbooks, (1ed. 1897) 1997.

NABUCO, Joaquim Discurso pronunciado em 29 de abril de 1879. In Gilberto Freyre (org.) Discursos parlamentares. Rio de Janeiro, 1950.

NOGUEIRA, Marco Aurélio. O encontro de Joaquim Nabuco coma política. As desventuras do liberalismo. São Paulo, Paz e Terra, 2010.

PINTO, Antônio Pereira (org.), Reforma eleitoral. Brasília Ed. UnB, (1a ed.1875) 1983.

POCOCK, J. G. A. Politics, language \& time: essays on political thought and history. Chicago: University of Chicago, 1989. .

PORTO, Walter Costa. O Voto no Brasil. Da Colônia à República. Brasília: Senado Federal, 1989.

ROSANVALLON, Pierre. Le Moment Guizot. France, Éditions Gallimard, 1985 .

SALES, Alberto. A Pátria Paulista. Brasília, Ed. UnB, (1.ed. 1887) 1983.

SANTOS, Wanderley Guilherme dos. Do autoritarismo político à sociedade desigualmente aberta. In Crise e 
Castigo: partidos e generais na política brasileira. Rio de Janeiro Vértice, 1987.

SANTOS, Wanderley Guilherme dos A teoria da democracia proporcional de José de Alencar. In SANTOS, W.G. (org.). Dois escritos democráticos, Rio de Janeiro, Ed. UFRJ, 1999.

SANTOS, Wanderley Guilherme dos. Paradigma e História: a ordem burguesa na imaginação social brasileira. A práxis liberal no Brasil: propostas para a reflexão e pesquisa. In Ordem burguesa e liberalismo político. São Paulo: Duas Cidades, 1978.

SARTORI, Giovanni, A política como ciência. In A Política. Brasília: Editora da Universidade de Brasília, 1981.

SCHWARCZ, Roberto. O nacional por subtração. In Que horas são? São Paulo, Companhia das Letras, 1989 : 46-47.

SCHWARCZ, Roberto. 2000, Ao vencedor as batatas. São Paulo: Duas Cidades: Ed. 34.

SIDENTOP, Larry, Two liberal traditions. In Alan Ryan (edited) The idea of freedom. Oxford University Press, 1979.

SOUZA, Braz Florentino de. Do Poder Moderador,. Brasília, Ed. Senado Federal, (1ed. 1864) 1978.

SOUZA, Francisco Belisário de. O sistema eleitoral no Império. Brasília, Ed. Senado Federal, (1 ed. 1872) 1978.

SOUZA, Paulino José Soares de Souza (Visconde do Uruguai), Ensaio sobre o Direito Administrativo. Brasília: Ministério da Justiça. 1997. (1ed. 1862).

TOCQUEVILLE, Alexis. A Democracia na América. EDUSP/Itatiaia. Minas Gerais/ São Paulo, 1979.

TORRES, João Camilo de Oliveira. A democracia coroada: Teoria política do Império do Brasil. Petrópolis: Editora Vozes, 1964.

VASCONCELOS, Bernardo Pereira de Carta aos eleitores da província de Minas Gerais. In Bernardo Pereira de Vasconcelos. Org. e introd. José Murilo de Carvalho, São Paulo, Ed. 34, (1.ed. 1827), 1999.

VASCONCELOS, Zacarias de Góis e, Da natureza e dos limites do Poder Moderador. In Zacarias de Góis e Vasconcelos, org. e introd. Ceilia Helena Salles de Oliveira. São Paulo, Ed. 34 (1ed 1860) 2002) 
WERNECK VIANNA, Luis e CARVALHO, Maria Alice Rezende de. - República e Civilização Brasileira. In Pensar a República. Newton Bignotto (org.). Belo Horizonte: Ed. UFMG, 2000.

WOLIN, Sheldon, 1969, Political Theory as a vocation. American Political Science Review, Washington, volume 63, n. 4, : 1063-1082. 